\title{
The Moderating Effect of Leader-member Exchange, Mediation and Employee Silence Behavior-organizational Trust Risk Avoidance
}

\author{
Mamatha N \\ Istanbul Aydin University, Institute of Graduate Students, Department of Business Administration (English) \\ FloryaKampüs, BeşyolMahallesi, İnönüCaddesi 38 Sefaköy, 34295 Küçükçekmece / İstanbul, Türkiye \\ mamathaneyin@gmail.com
}

\begin{abstract}
Employee Performance is has been taken seriously in organization in recent years. The effort that employee show to increase their performance, is taking in consideration while organization is hiring an employee. Beside this, leadership is important factor to help employee perform in the best way and help organization success. Somehow toxic leadership has a negative affect on this success and decrease in employee performance. Having a toxic leader in organization make some employee to remain silent, and stay away from voluntary work which is known as contextual performance. The aim of the study is to show the relationship of toxic leadership and contextual performance, while employee silence as a mediator role between these relationships. The data collected through online survey. 400 people participated in the survey, which $\% 52$ of them is female and \%48 is male. The survey divided into four sections: demographic information, organizational silence scale, toxic leadership scale and contextual performance scale. For analyzing the data, SPSS program was used. Different tests were used to look at the differences between the variables in terms of demographic characteristics. Significant findings were obtained for the gender, age, job, and organizational tenure categories.
\end{abstract}

Keywords: Toxic leadership, contextual performance, employee silence, organization silence

\section{Introduction}

\subsection{The Purpose of The Study}

This research examines the dimension of disorder that happen in organization as a result of toxic or narcissism leadership behaviors. The study shows how the toxic leadership behavior affects employee silence and it gives a way to decrease contextual performance of an employee. This study gives more consideration to the affect that toxic or narcissism leadership behaviors have on the whole business climate of the organization (Leet, 2011).

The relationship between toxic leadership behaviors and organizational performance, according to the researchers, is equivocal, and further study is needed to discover and understand the underlying processes and mechanisms (Mackey et al., 2015). Toxic behaviors lead to counterproductivity, according to thorough literature evaluations (Goldman, 2009) and these actions tend to fall down, corrupting the entire organizational climate (Mawritz et al.2012). In a toxic leadership environment, those who use their mental resources, critical thinking, and questioning abilities more completely are kept out of decision-making and positions of authority, while people who engage their mental resources, critical thinking, and questioning skills more fully are rewarded and promoted to leadership roles (Wilson-Starks, 2003). A toxic leader may not be particularly productive since toxic leadership causes poor interactions between leaders and employees(Higgs \& Rowland , 2009). It's not about being a success or failure in terms of metrics or productivity when it comes to toxic leadership. It's about having negative impacts on people that lead to terrible actions and behaviors (Edwards et al., 2015). Kusy \& Holloway (2009) agree that "A toxic leader is not the same as a tough coworker; rather, a toxic leader is someone who has an impact on others' job performance and workplace quality of life".

When organizations have toxic climates, people are reticent to share their experiences and feel uncomfortable sharing the issues they face at work. This is because the leaders may have a bad perception of their abilities or undervalues their efforts(Schilling \& Kluge, 2009).

$\mathrm{Xu}$, Loi, and Lam (2015) mention that employees are silenced by harsh monitoring, a component of toxic leadership conduct, since they are exhausted. Leaders have an important role in employee silence because they determine how much it costs to speak up (Milliken et al. 2003).

Employee silence, which acts as a barrier to upward communication, keeps organizational decision makers in the dark about the organization's ground realities and challenges, causing delays in timely and meaningful decision making and, as a result, lowering organizational performance (Schilling \& Kluge, 2009).

\subsection{Research Hypotheses}

Zellars and Tepper (2002) mention that toxic leadership has been described as a kind of leadership that results in counterproductive work behaviors and outcomes in employees. This viewpoint is consistent with the majority of research, which has characterized toxic leadership as detrimental and counterproductive to performance (Goldman, 2009). Other authors like (Ferris et al.2007) have pointed out that dysfunctional leaders may have beneficial results that help organizations in the short term. They observed that some employees are working hard and give their all to satisfy the demands of their leaders, either as a 
result of the manager's pressure or because of their connection with the leader. According to their research, (Dasborough \& Ashkanasy, 2002) say that toxic leaders with emotion-evoking actions have a negative impact on employee behavior and productivity.

Many studies show the relationship between toxic leadership and contextual performance. As a result, the studies show negative impact of toxic leadership on contextual performance.

H1: The toxic leadership style has negative impact on contextual performance

Toxic leadership behaviors are emotionally exhausting, resulting in emotional exhaustion and employee silence $(\mathrm{Ng}$ \& Feldman, 2012). According toTepper B. (2007), Employees who are confronted with their toxic leader's bad conduct prefer to adopt socially anxious or passive copping actions by avoiding direct contact with them, based on the concept of resource conservation.

H2: The toxic leadership has positive impact on employee silence

When employees are afraid to offer information owing to the leadership's refusal to collaborate, employee silence becomes an issue(Morrison E. W., 2014). Employee silence might be related to the personality of the follower, leadership effectiveness, or socio-cultural reasons including power distance and disagreement with corporate norms and values(Schilling \& Kluge, 2009). Employee silence is regarded as a problematic behavior that obstructs organizational transformation and lowers positive job attitudes such as job satisfaction and dedication (Vakol \& Bouradas, 2005). Employee silence is a wide term that encompasses both expressive and repressive open decisions made by employees (Milliken et al.2003).

H3: Employee silence has negative impact on contextual performance in organization

This study examining the whole negative impact of toxic leadership behavior has on contextual performance and employee silence. It shows the consequences of toxic behavior on organization performance.

H4: Employee silence is an important mediator on the relationship between toxic leadership and contextual performance in an organization.

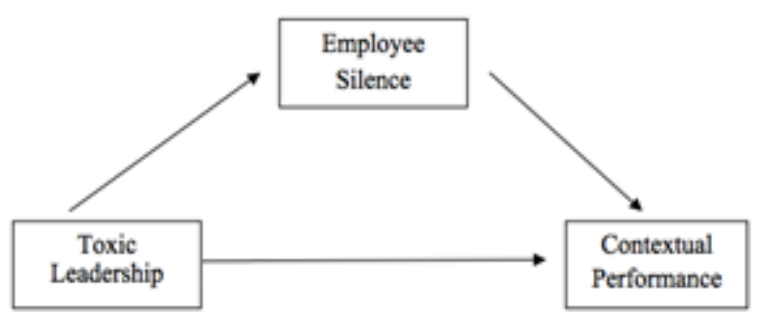

Figure 1: The Research Model

\subsection{The Importance of The Research}

Leaders are most important element of organizational success; also in some way it can be the most toxic element and obstacle for the success inside organization. Despite decades of efforts to rid organizations of toxic leadership, the problem continues (Morris, 2019). Toxic leadership inside organization affects employee and their performance as well. According to the literature, toxic behaviors lead to unproductive work settings, employee silence and higher levels of psychological discomfort (Zellars \& Tepper, 2002). Contextual performance may be defined as a set of voluntary actions that aid in the achievement of the work's motivational and social framework (Van Scotter \& Motowidlo, 1996). Because of the emphasis on team-based work, contextual performance is becoming increasingly important for organization to consider (Fletcher, 2001). Understanding contextual performance is another main part of this research. It also shows how toxic leadership affects negatively on employee and decrease contextual performance inside organization.

Employee silence means a lack of concern on the part of the workforce. Employees that are unconcerned with their company's principles may disregard them, resulting in a lack of quality in their work (Joinson, 1996). Employee silence is a deliberate conduct in which workers keep silent about organizational difficulties by not communicating their true feelings with those who can make adjustments and corrections at the organizational level (Pinder \& Harlos, 2001). Employee silence is examined in this research as a negative impact on contextual performance.

The research has helped to uncover the mechanism behind the link between toxic leadership, employee silence, and contextual performance. Also, the research proposed methods for demonstrating toxic leadership, as well as developing processes and treatments that, on the one hand, grow leaders at the same time, employees and organizations will be able to cope with toxic leadership practices. The research also contributed to the literature by addressing the function of employee silence in mediating the relationship between toxic leadership behaviors and contextual performance.

\section{Literature Review}

\subsection{Toxic Leadership}

There are many topics that talk about positive leadership, but neglect about how toxic behaviors affects on effectiveness of organization. Toxic leadership is a topic that becomes more interest in our daily life. Toxic behaviors affect on the culture and community, it draw a toxic path to the members of society. Toxic leadership is a type of leadership in which leaders cause long-term and considerable harm to their followers and, indirectly, to their organizations, as a result of their poor conduct and personal qualities(Mehta \& Maheshwari , 2014). Toxic leadership can also be defined as as destructive leadership and considered by the researchers with limited scope (e. g. abusive supervision, bullying, narcissism, pity tyranny etc.) and covered only one or two viewpoints of the toxicity on the organizational level factors 
(Saqib \& Arif , 2017). Transactional leaders and difficult personalities are not the same as toxic leaders (Edwards \& McGrath, 2012). Schmidt (2008) described toxic leaders succinctly as "narcissistic, self-promoters who engage in an unpredictable pattern of abusive and authoritarian supervision".

Toxic leadership may have negative consequences for both organizations and employees, causing harm to the workplace (Morris, 2019). Toxic leaders advance their bad personality and doesn't cares about others but themselves. With their destructive behaviors and attitudes, they diminish employee motivation and productivity. Toxic leaders also force their employees to speak in hushed tones, and they frequently backbite and dismiss their employees (Flynn, 1999). They make scapegoats for problems and point the finger at others when things go wrong in the organization (Akca, 2017). Toxic leaders are creating an environment that is fix their mindset and where followers are rewarded for agreeing with their toxicity behavior. The harmful behavior that toxic leaders build on organization may show the negative impact after some years. Mood, creativity, and organization performance that employee doesn't show off, are all the consequences of toxic leaders(Maxwell, 2015).

Goldman (2009) define toxic leadership as "being harmful, upsetting, and dysfunctional forms of management that proliferate among employees". Flynn (1999) Brief the affects of toxic leadership on working environment "A leader who bullies, threatens, and screams at his employees. On any given workday, the tone of the organization is set by the leader's mood swings. Who is it that drives employees to commiserate in their cubicles and hallways". When there is a poisonous environment, the organization's rules and culture are changed to accommodate the virulent behavior(Roter, 2011). It's not always a leader's attitude or communication style that makes them toxic, the systemic discouraging effects are frequently indicative of toxic dynamics (Burton et al.2012). Toxic leaders may be extremely capable and effective at their positions (Estes, 2013), however, they contribute to a toxic environment among their colleagues and subordinates, which has far-reaching implications that go beyond the morale of a few victims (Mawritz M. et al., 2012).

Toxic leadership has a number of drawbacks, including low work satisfaction (Ghosh et al.2011), a rise in employee absenteeism (Goldman, 2009), decreasing employee enthusiasm and productivity (Cortina, 2001), increasing drug and alcohol misuse and employee turnover has increased (Starratt \& Grandy, 2010). Workers' sociological, physical, and psychological well being are all negatively impacted by a hazardous workplace (Harvey \& Too, 2012). Frost (1999) say that there are two forms of toxic leadership. One is a form of leadership and organizational conduct that brings people and organizations pain and misery. The other linked leaders to demonstrating sympathy to people in the workplace, which resulted in worse performance.

Disadvantaging employees, choosing to ignore ideas, delegitimizing, bullying, feelings volatility, blaming others for one's own mistakes, ignoring employees' employment rights, mocking lying, pitting group members, and shutting out group members are just a few of the featured toxic leadership behaviors by leaders(Pelletier, 2010). While abusive supervision creates an atmosphere that is unfavorable to creativity, loyalty, and well-being, it does not contain the poisonous leadership traits of narcissism and authoritarianism (Hitchcock, 2015). Toxic leadership behaviors intoxicate employees and the organization. Employees are agitated by toxic leader's negative behaviors (Koçel, 2020).

Toxic leads are available in a variety of forms and sizes Actively toxic leaders intentionally damage others or enrich themselves at the expense of others, whereas inadvertently toxic leaders inflict severe harm to others via negligent or irresponsible actions, as well as ineptitude. To make matters more complicated, leaders appear differently based on one's connection with them. As a result, my toxic leader may become your idol, and vice versa (Lipman-Blumen, 2005). Lipman-Blumen (2005) also say that even most toxic leaders is not always very harmful and toxic. In certain cases, a single leader is toxic, but in other cases, he or she is not. The same leader may exhibit different forms and degrees of toxicity at different times in the same situation. Furthermore, different toxic leaders exhibit different types and degrees of toxicity, and the repercussions of their actions may cause various sorts and levels of harm(Lipman-Blumen, 2005).

\subsection{Contextual Performance}

Katz's work from the early 1960s introduced the investigation of contextual performance. Katz (1964) examines a range of employee attitudes that are linked to organizational efficiency. According to him, there are three types of requirements for good organization functioning: people must be persuaded to enter and remain in the system, they must be dependable in their job obligations, and personnel must be spontaneous and imaginative in order to achieve organizational objectives that are outside of their function criteria. Despite the fact that Katz does not label these needs, he recognizes the importance of employees' desire to both complete their obligatory tasks and pass on their job expectations (Borman \& Motowidlo, 1997).

Job performance, according to researchers and practitioners, is multifaceted and consists of two key factors: task performance and contextual performance. (Motowidlo \& Schmit, 1999). There are numerous approaches to discern contextual performance from task performance(Reilly \& Aronson , 2012). Task performance is critical because it pertains to the production of job-specific goods and services and necessitates the acquisition and demonstration of key technical abilities by employees. Employee discretionary behaviors that are not directly related to their core task requirements as stated in the job description, on the other hand, can enhance organizational efficiency and effectiveness (Goodman \& Svyantek, 1999). As a result, task performance is linked to the organization's technological core, either through the execution of technical procedures or the maintenance and servicing of technical requirements (Motowidloet al., 1997).

Contextual performance, while important for task performance, improves the organizational climate by 
strengthening social networks. Employees who engage in contextual performance contribute to the organization's culture and climate. Because people volunteer for extra work, persevere with passion, and support and cooperate with others, contextual performance has the potential to revolutionize the organization (Motowidlo \& Schmit, 1999). Contextual performance refers to activities that are not task or goal specific but improve the effectiveness and success of individuals, teams, and organizations. Contextual performance includes cooperating and assisting others, voluntary basis performing extra-role activities, persisting with optimism and extra dedication to finish tasks successfully, trying to defend the organization's goals, and complying to organizational policies even when it is inconvenient(Reilly \& Aronson , 2012). Contextual activities, on the other hand, are elective; discretionary actions oriented toward other people or the organization as a whole. (Organ, 1988). According to a study, personality traits are more efficient indicators of contextual performance than task performance (Borman \& Motowidlo, 1997).

Contextual performance, according to Kell and Motowidlo (2013), is defined as conduct that adds to organizational success through its effects on the psychological, emotional, and organizational environment of work. Employees may make a difference in the workplace in a variety of ways. Ingroup contexts, contextual performance is very essential. Teamwork is aided by interpersonal assistance, job devotion, and initiative that reflects contextual performance (Reilly \& Aronson , 2012). Information sharing and acts of kindness might be considered necessary skills for good teamwork (LePine, et al., 2000).

Contextual performance refers to the whole expected value of an individual's actions over a period of time for maintaining and enhancing the psychological, social, and organizational environment of work. These definitions recognize that some behaviors may have repercussions for both the production of products and services as well as the maintenance and enhancement of the psychological, social, and organizational context of work. (Kell \& Motowidlo , 2013).

In a number of ways, leaders' actions can have an impact on followers' contextual performance (Reilly \& Aronson , 2012). According to research, more experienced managers place a higher emphasis on contextual performance than less experienced managers (Befort \& Hattrup, 2003).

\subsection{Employee Silence}

Employees are considered as the organization's most valuable asset. Employees have a critical role in change, creativity, and innovation, all of which are important aspects in achieving organizational goals, yet they frequently choose to keep silent rather than express their valued ideas and concerns about problems in their workplaces. On the other hand, Managerial choices have the greatest influence on the conduct of an organization's members. Managers must comprehend why employees act the way they do. Employee silences and voices must be understood in general if the organization is to fulfill performance goals. Employees frequently provide helpful ideas, knowledge, and opinions on how to enhance work and work organizations. These personnel may communicate their thoughts, information, and opinions at times, but they may also keep mute and suppress their ideas, information, and opinions at other times.

Because silence is a sort of communication in and of itself, encompassing a range of cognitions, emotions, and purposes such as opposition or affirmation, it is defined as the absence of sound(Pinder \& Harlos, 2001). Organizational silence is viewed as collective phenomena that impede the growth of pluralistic organizations. (Morrison \& Milliken, 2000). Employee silence is regarded as a problematic habit that obstructs organizational development and lowers positive job attitudes such as job satisfaction and dedication(Vakola \& Bouradas, 2005). Employee silence refers to a larger spectrum of activities by employees, including both expressive and oppressive open decisions(Hewlin, 2003). A variety of empirical and conceptual studies have been performed to discover the causes for employee silence in the face of potential organizational challenges(Brinsfield, 2013). People keep quiet to avoid humiliation, conflict, or other perceived threats. (Perlow \& Williams, 2003). Silence, on the other hand, may communicate acceptance and sharing, as well as disapproval and resistance, and therefore serves as a pressure mechanism for both people and organizations (Bagheri, et al., 2012). Employees' intentions on dynamic necessary information and issues in relation to workplace difficulties are held in silence. It is not a case of noncommunication; rather, it is a choice made by individuals to not report concerns, withhold advice, and keeps mute in the workplace(Pinder \& Harlos, 2001). As a result, research in this field suggests that silence is a disconnected unproductive work behavior that is most likely harmful to organizations (Bolton, et al., 2012). Communication difficulties connected to basic employment issues, in particular, can provide a challenge to the current state of affairs and the expert, whose esteem may be more important than available resources, or even lead to future valuable asset exhaustion(Ng, et al., 2012). Tepper (2007) acknowledge that most subordinates under abusive supervision are affected by assertiveness to keep silent due to fear of recourse loss, according to research that the effect of abusive supervision is guided by features of their workers and environment. Furthermore, we recognize that lowassertive employees who experience increased anxiety as a result of abusive supervision will not engage in organizational reform concerns and will keep silent owing to the high social and instrumental stakes associated with attesting themselves. Because of the negative consequences of abusive supervision, the current study focuses on silence; an unfavorable state of voice such as "failure to speak" (Morrison E. W., 2011).

Park and Keil (2009) take a three-dimensional look into employee silence. First, silence may be purposeful. Even if they are aware of the problem and have a better solution, employees keep quite and recommend saying nothing. Second, silence may be used as a form of protection. Employees might choose to keep silent in order to preserve their interests or avoid publicly contradicting others. Finally, employee silence may be a communal decision; a collective reaction to not sharing ideas, thoughts, or knowledge with others. 
Many employees in today's workplaces choose to keep silent when potentially significant concerns occur(Tangirala \& Ramanujam, 2008). Employees are not allowed to voice their thoughts and objections to their superiors, even if they have concerns regarding work-related issues such as the rudeness of others or underlying dangers inside their organization (Morrison, 2011). According to a poll conducted by Milliken, Morrison, and Hewlin (2003), 85\% of employees withheld essential job information on purpose, and $50 \%$ confessed that discussing organizational problems would make them uncomfortable. Silence can be advantageous in some aspects, such as reducing superfluous information, reducing interpersonal problems, and increasing information privacy among coworkers (Morrison $\&$ Milliken, 2000). Employee silence, on the other hand, not only obstructs information flow and decision-making, but it also reduces employee pleasure and job engagement in the majority of cases (Milliken et al, 2003).

Many employees in today's workplaces choose to keep silent when potentially significant concerns occur (Tangirala \& Ramanujam, 2008). Employees are not allowed to voice their thoughts and objections to their superiors, even if they have concerns regarding work-related issues such as the rudeness of others or underlying dangers inside their organization (Morrison, 2011). According to a poll conducted by Milliken, Morrison, and Hewlin (2003), 85\% of employees withheld essential job information on purpose, and $50 \%$ confessed that discussing organizational problems would make them uncomfortable. Silence can be advantageous in some aspects, such as reducing superfluous information, reducing interpersonal problems, and increasing information privacy among coworkers (Morrison $\&$ Milliken, 2000). Employee silence, on the other hand, not only obstructs information flow and decision-making, but it also reduces employee pleasure and job engagement in the majority of cases (Milliken et al, 2003).

\section{Methodology}

\subsection{Sample}

The data was gathered randomly from 400 employees, who they work for different companies in different sectors. $\% 52$ of the attendance were female and $\% 48$ of were male, with the average age of 33. The aim of this data is to show the affect of employee's contextual performance under toxic leaders, and how the employee silence affects it. As a result we can see how employee react to toxic leaders in organization. The data is also show even employee keep silent when they face toxic and destructive leaders in their organization.

\subsection{Research Instruments}

Three measures were utilized to investigate the function of employee silence as a mediator between toxic leadership and contextual performance in this study. There were 65 items in total and 8 demographics questions were asked from the attendance to see better result and made the research more reliable.

\subsection{Procedure}

The items and questionnaires sent to the participants via online by taking help from a professional company that make research. From that online survey, data collected from 400 employees from different sector, different business category all around Turkey. We gave information about the study and ensured the participants about their answers that will only use for an academic research.

\subsection{Data Analysis}

The result of the research was analyzed by Statistical Package for the Social Sciences (SPSS). Correlation analysis applied to see if the variables are related to each other. This analysis presents also the type and violence of the relationships among the variables.

Then the regression analysis conducted to see how the variables in the study explain their effects on the dependent variable. The regression in SPSS was made by stepwise. By this mode, for every model in regression, the significant values from the previous step are included in; so the weakened variables are removed from the models. That is why the stepwise mode is the most frequently method used in regression analysis in SPSS (George \&Mallery, 2003).

To test the demographic differences of the variables, Kruskal-Wallis rank sum test was used. Parametric and nonparametric tests are two types of difference tests. Nonparametric tests were utilized in this investigation because the variables' normality conditions were not specified.

\section{Finding}

\subsection{Factor Analysis and Internal Consistencies}

To begin analysis for toxic leadership, the Kaiser-MeyerOlkin (KMO) sample adequacy test and Bartlett's Test of Sphericity were performed to see if the data for this variable could be factored. The KMO value was 0.96 , and the Bartlett's Test of Sphericity resulted in a significant result ( $\mathrm{p}$ $=0.0000 .001$ ).

When the reliably of these factors were examined, it was seen that the Cronbach's alpha values for them led them to a high internal consistency $\left(\alpha_{\text {abusive }}=0.980 \alpha_{\text {narcissist }}=0.907\right.$ and $\alpha_{\text {unpredictable }}=0.956$ ).

In the beginning of the factor analysis for organizational silence, Kaiser-Meyer-Olkin (KMO) measure of sampling adequacy test and Bartlett's Test of Sphericity demonstrated that the data was convenient to go under this analysis ( $p$ $=.000<.001)$. But the rotated component matrix signed that only one component was extracted. The solution could not be rotated. In this case, the analysis was repeated forcing it to the three factors as in the literature (Çavuşoğlu\&Köse, 2019). But the factors were seen not be distributed similarly as the previous study. Finally the variable was taken as a single factor into consideration. As a whole factor, the reliability analysis of organizational silence was found high (Cronbach's $\alpha=0.977$ ). 
Kaiser-Meyer-Olkin (KMO) measure of sampling adequacy test and Bartlett's Test of Sphericity for contextual performance revealed significant value in order to conduct or analysis $(\mathrm{p}=.000<.001)$. Similar to the previous study (Borman\&Motowidlo, 1997) the analysis showed two factors. In this study the factors were named as volunteered and social performance.

\subsection{Correlation and Regression Analysis}

All of the factors and composite variables have substantial relationships, as shown in the table. At the 0.01 levels, all of the correlations are significant.

Table 1: Correlation Test

\begin{tabular}{|l|c|c|c|c|c|c|c|c|}
\hline & 1 & 2 & 3 & 4 & 5 & 6 & 7 & 8 \\
\hline 1. Abusive leader & 1 & & & & & & & \\
\hline 2. Narcissist leader &, $633^{* *}$ & 1 & & & & & & \\
\hline 3. Unpredictable leader &, $806^{* *}$ &, $793^{* *}$ & 1 & & & & & \\
\hline 4. Toxic leader &, $924^{* *}$ &, $837^{* *}$ &, $949^{* *}$ & 1 & & & & \\
\hline 5. Silence &, $529^{* *}$ &, $478^{* *}$ &, $503^{* *}$ &, $555^{* *}$ & 1 & & & \\
\hline 6. Volunteered perf. &, $207^{* *}$ &, $471^{* *}$ &, $262^{* *}$ &, $307^{* *}$ &, $240^{* *}$ & 1 & & \\
\hline 7. Social perf. &, $259^{* *}$ &, $538^{* *}$ &, $298^{* *}$ &, $359^{* *}$ &, $363^{* *}$ &, $806^{* *}$ & 1 & \\
\hline 8. Performance &, $247^{* *}$ &, $516^{* *}$ &, $286^{* *}$ &, $343^{* *}$ &, $299^{* *}$ &, $946^{* *}$ &, $940^{* *}$ & 1 \\
\hline
\end{tabular}

When the associations between the variables are analyzed, however, they are not found to be at the same level. The correlation between independent and dependent variable is significant positive one $(\mathrm{r}=0.343, \mathrm{p}<0.01)$, which is a weak relationship. Among the sub factors of toxic leadership, the most correlated on with contextual performance is the narcissist leadership $(r=0.516, p<0.01)$. As for the relationship between independent variable and the mediator, it is found to be moderate positive correlation $(\mathrm{r}=$ $0.555, \mathrm{p}<0.01)$. This is the highest correlation among toxic leadership factors and organizational silence. Lastly, the correlation between the dependent variable and the mediator is the weakest one $(r=0.299, p<0.01)$. As a result of this correlation analysis, it can be said that none of the variables had a higher correlation than 0.70 which means that there's no deal of multi-collinearity. According to this, the research model is said to be reliable.

In Table 2 the regression is simply conducted both with the independent variable as a single factor and multiply with its subfactors. According to the first model, it is seen that the toxic leadership significantly explains organizational silence. In the first model regression analysis, it was determined that toxic leadership alone explained a significant almost $30 \%$ variance of organizational silence in the first model $(\beta=$ $0.543 ; \mathrm{p}<0.05)$.

For the second model in coefficient table, $t_{\text {abusive leadership }}=$ 4.672 and $t_{\text {Narcissist leadership }}=3.043$ and it is significant $(\mathrm{p}=$ $0.001<0.05)$. This approves the validity of the model. Accordingly, the equation of the first model is:

Organizational Silence $=3.379+(0.263) *$ Abusive leadership $+(0.23) *$ Narcissist leadership

Table 2: Regression AnalysesI

\begin{tabular}{|c|c|c|c|c|}
\hline \multicolumn{5}{|c|}{ Dependent Variable: Organizational silence } \\
\hline & Variables & Beta & $\mathrm{t}$ & $\mathrm{p}$ \\
\hline Model 1 & & & \\
\hline & Toxic leadership & 0,543 & 13,036 & 0,000 \\
\hline $\mathrm{R}=0,547 ; \mathrm{R} 2=0,299 ; \mathrm{F}=169,931 ; \mathrm{p}=0,000$ \\
\hline Model 2 & & & \\
\hline & Abusive leadership & 0,263 & 4,672 & 0,000 \\
\hline & Narcissist leadership & 0,23 & 3,043 & 0,002 \\
\hline $\mathrm{R}=0,551 \mathrm{R} 2=0,304 ; \mathrm{F}=57,679 ; \mathrm{p}=0,000$ \\
\hline
\end{tabular}

The second model shows that toxic leadership can statistically explain the contextual performance $\left(\mathrm{R}^{2}=0.128\right.$, $\mathrm{p}=0.000<0.05$ ) as shown in table 3 . But this effect is found to be positive. The following model tests the impact of organizational silence on contextual performance. The hypothesis 3 suggests that organizational silence has negative impact on contextual performance in organization. The model brought out the positive impact of organizational silence on contextual performance $\left(\mathrm{R}^{2}=0.125, \mathrm{p}=0.000\right.$ $<0.05)$.

Table 3: Regression Analyses II

\begin{tabular}{|c|c|c|c|c|}
\hline \multicolumn{5}{|c|}{ Dependent Variable: Contextual performance } \\
\hline & Variables & Beta & $\mathrm{t}$ & $\mathrm{p}$ \\
\hline \multicolumn{5}{|l|}{ Model 1} \\
\hline & Toxic leadership & 0,255 & 7,64 & 0,000 \\
\hline \multicolumn{5}{|c|}{$\mathrm{R}=0,358 ; \mathrm{R} 2=0,128 ; \mathrm{F}=58,370 ; \mathrm{p}=0,000$} \\
\hline \multicolumn{5}{|c|}{ 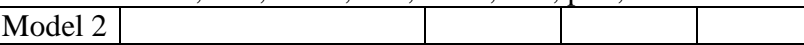 } \\
\hline & Organizational silence & 0,254 & 7,539 & 0,000 \\
\hline \multicolumn{5}{|c|}{$\mathrm{R}=0,354 \mathrm{R} 2=0,125 ; \mathrm{F}=56,843 ; \mathrm{p}=0,000$} \\
\hline Model 3 & & & & \\
\hline & Toxic leadership & 0,167 & 4,275 & 0,000 \\
\hline & Organizational silence & 0,162 & 4,109 & 0,000 \\
\hline
\end{tabular}

\subsection{Different Tests}

Table 4 shows that there is a significant difference of abusive leadership ( $\mathrm{p}=0.042<0.05)$ and organizational silence $(\mathrm{p}=0.000<0.05)$ in terms of age groups. Regarding abusive leadership, the $\left(\mu\right.$ Rank $_{\text {Female }}=124.39$, $\mu$ Rank $\left._{\text {Male }}=104.20\right)$. The highest perception of such leadership style is seen in the younger age group ( $\mu \operatorname{Rank}_{18-25}$ $=234)$; whereas the oldest group perceive it the least $\left(\mu \operatorname{Rank}_{18-25}=173,83\right)$.

Organizational silence is found to be increase as the age increases up to a level $\left(\mu \operatorname{Rank}_{18-25}=192,07 ; \mu \operatorname{Rank}_{26-30}=\right.$ $231,23)$. As the age continues to increase after this point, organizational silence shows a decrease $\left(\mu \operatorname{Rank}_{31-40}=177\right.$, $\left.18 ; \mu \operatorname{Rank}_{41-45}=196,16 ; \mu \operatorname{Rank}_{46+}=85\right)$.

In terms of education, it is seen that as the level of education gets higher, the. level of contextual performance gets higher too $\left(\mu \operatorname{Rank}_{\text {high school }}=174,84, \mu\right.$ Rank $_{\text {vocational school }}=197$; 
$\mu$ Rank $_{\text {Bachelor }}=210,24 ; \mu$ Rank $\left._{\text {Postgraduate }}=242,88\right)$. This shows a positive relationship between education and employee's contextual performance.

Table 4: Different Test for age groups

\begin{tabular}{|c|c|c|c|c|c|}
\hline & & $\mathrm{N}$ & Mean & p- value & Chi-Square \\
\hline \multirow{5}{*}{$\begin{array}{l}\text { Abusive } \\
\text { leadership }\end{array}$} & $18-25$ & 42 & 234,5 & \multirow{5}{*}{0,042} & \multirow{5}{*}{9,909} \\
\hline & $26-30$ & 166 & 210,81 & & \\
\hline & $31-40$ & 136 & 179,95 & & \\
\hline & $41-45$ & 44 & 199,93 & & \\
\hline & 46 plus & 12 & 173,83 & & \\
\hline \multirow{5}{*}{ Org. silence } & $18-25$ & 42 & 192,07 & \multirow{5}{*}{0,000} & \multirow{5}{*}{29,583} \\
\hline & $26-30$ & 166 & 231,23 & & \\
\hline & $31-40$ & 136 & 177,18 & & \\
\hline & $41-45$ & 44 & 196,16 & & \\
\hline & 46 plus & 12 & 85 & & \\
\hline
\end{tabular}

Table 5: Different Tests for Education Group

\begin{tabular}{|c|c|c|c|c|c|}
\hline \multicolumn{2}{|c|}{} & N & Mean & $\begin{array}{c}\mathrm{p} \\
\text { value }\end{array}$ & $\begin{array}{c}\text { Chi- } \\
\text { Square }\end{array}$ \\
\hline \multirow{3}{*}{$\begin{array}{c}\text { Contextual } \\
\text { performance }\end{array}$} & High school & 87 & 174,84 & & \\
\cline { 2 - 5 } & Vocational school & 92 & 197 & \multirow{2}{*}{0,000} & 20,272 \\
\cline { 2 - 4 } & $\begin{array}{c}\text { Bachelor Post } \\
\text { graduate }\end{array}$ & 189 & 210,24 & & \\
& 32 & 242,88 & & \\
\hline
\end{tabular}

\section{Conclusion, Discussion and Limitation for Future Study}

The aim of this study is to show the relationship between toxic leadership and contextual performance. The role of organizational silence was taken in consideration to see the affect of employee performance in organization.

We did the correlation analysis to see the relationship between variables. The analysis shows that the relationship between toxic leadership and contextual performance is significant positive, which is a weak relationship. Narcissist leadership style is the most correlated sub factor of toxic leadership with contextual performance. The study shows that having a narcissist leader have negative impact on contextual performance. This result is line with other literatures like Lipman-Blumen (2005), he says that having a toxic leadership in an organization decrease employee perfoarmance, job satisfaction and commitment, so that there should be a concerted effort to limit the possibility of such destructive behavior by toxic leadership style. The study by Aboyassin and Abood (2013) shows that ineffective leadership has been demonstrated to have a detrimental influence on employee and organizational performance. Also toxic leadership and organizational silence is found to be in moderate positive correlation.

Then the regression analysis applied to see the effects of variables on dependent variable. According to the first model of regression analysis, it is seen that the toxic leadership significantly explains organizational silence. In this case the second hypothesis is supported which was "the toxic leadership has positive impact on employee silence". This is consistent with pervious studies (Saqib \& Arif, 2017; Tepper B., 2007; Goldman, 2009). According to these scholars, Toxic leadership has the ability to cascade down and negatively effect employees, producing emotional weariness and silent.
Although this study yielded interesting results, it had certain limitations that need to be investigated further. On the one hand, our study focused on the impact of toxic leadership style on employee behavior in the organization, but it didn't look at how toxic and dysfunctional leadership affects employee's behavior outside of the organization.

Another limitation is that the survey sent to participants randomly and not chosen those employees that faced toxic leaders in their workplace. This may help to find better result from employee that really experienced toxic leaders. Hence, preferably, scholars ought to measure the various variables from different sources in future.

Furthermore, the current study's analysis was done at the employee level. As a result, future research might build on these linkages and look at them from a group viewpoint, or can be try on the managers in organization.

Beside these limitations, it's recommended for future study to take other variables and test it with toxic leadership variable. Toxic leadership study is getting more in attraction in recent years by researchers, as more employee experience and face toxic leadership style in working place and organization.

\section{References}

[1] Mawritz, M., Mayer, D., Hoobler, J., Wayne, S., \& Marinova, S. (2012). A Trickle-Down Model Of Abusive Supervision. Personnel Psychology.

[2] Koçel, T. (2020). Işletme Yöneticiliği.

[3] Zellars, K., \& Tepper, B. (2002). Abusive Supervision and Subordinates' Organizational Citizenship Behavior. Journal of Applied Psychology.

[4] Wilson-Starks, K. Y. (2003). Toxic Leadership. TRANSLEADERSHIP, INC.

[5] Vakol, M., \& Bouradas, D. (2005). Antecedents and consequences of organisational silence: An empirical investigation. Employee Relations.

[6] Vakola, M., \& Bouradas, D. (2005). Antecedents and consequences of organisational silence: An empirical investigation. Employee Relations.

[7] Van Scotter, J., \& Motowidlo, S. (1996). Interpersonal facilitation and job dedication as separate facets of contextual performance. Journal of Applied Psychology.

[8] Akca, M. (2017). The Impact of Toxic Leadership on Intention to Leave of Employees. International Journal of Economics, Business and Management Research.

[9] Ashforth, B. (1994). Petty Tyranny in Organizations. Human Relations.

[10] Bagheri, S., Kousha, A., \& Janati, A. (2012). Factors Influencing the Job Satisfaction of Health System Employees in Tabriz, Iran. Health Promot Perspect.

[11] Befort, N., \& Hattrup, K. (2003). Valuing Task and Contextual Performance: Experience, Job Roles, and Ratings of the Importance of Job Behaviors. Applied H. R. M. Research.

[12] Bennis, W., \& Townsend, R. (1995). Reinventing Leadership: Strategies to Empower the Organization. 
[13] Borman, W., \& Motowidlo, S. (1997, June). Task performance and contextual performance: The meaning for personnel selection research. Human performance, 99-109.

[14] Brinsfield, C. T. (2013). Employee silence motives: Investigation of dimensionality and development of measures. Journal of Organizational Behavior.

[15] Cortina, L. m. (2001). Incivility in the Workplace: Incidence and Impact. Journal of Occupational Health Psychology.

[16] Edwards, H., \& McGrath, H. (2012). Difficult Personalities. Australia: Penguin Random House.

[17] Estes, B. (2013). Abusive Supervision and Nursing Performance. Nursing form.

[18] Dasborough, M., \& Ashkanasy, N. (2002). Emotion and attribution of intentionality in leader-member relationships. In The Leadership Quarterly.

[19] Flynn, J. R. (1999). Searching for justice: The discovery of IQ gains over time. American Psychologist.

[20] Fletcher, C. (2001). Performance appraisal and management: The developing research agenda. Journal of Occupational and Organizational Psychology.

[21] Guerra, S. J. (2015). Contextual performance: An exploration of individual job performance and its relationship with patient contact. Dissertations \& Theses Capella University.

[22] Goldman, A. (2009). Transforming Toxic Leaders.

[23] Goodman, S., \& Svyantek, D. (1999). Personorganization fit and contextual performance: Do shared values matter. Journal of Vocational Behavior.

[24] Handy, c. (1992). the language of leadership. frontiers of leadership oxford blackwell.

[25] Harvey, M., \& Too, L. (2012). "TOXIC" workplaces: The negative interface between the physical and social environments. Journal of Corporate Real Estate.

[26] Hewlin, P. F. (2003). And the award for best actor goes to. . . Facades of conformity in organizational settings. The Academy of Management Review.

[27] Higgs, M., \& Rowland, D. (2009). Change leadership: case study of a global energy company.

[28] Hitchcock, M. J. (2015). The Relationship Between Toxic Leadership, Organizational Citizenship, and Turnover Behaviors Among San Diego Nonprofit Paid Staff. University of San Diego.

[29] Joinson, C. (1996). Recreating the Indifferent Employee. HRM Magazine.

[30] Kucuk, B. A. (2019). THE EXAMINATION OF THE IMPACT OF WORKPLACE ENVY ON INDIVIDUAL OUTCOMES OF COUNTERPRODUCTIVE WORK BEHAVIOR AND CONTEXTUAL PERFORMANCE: THE ROLE OF SELF-CONTROL. Suleyman Demirel University Journal of Faculty of Economics \& Administrative Sciences.

[31] Katz, D. (1964). The motivational basis of organizational behavior. Behavioral Science.

[32] Kell, H., \& Motowidlo, S. (2013, January). Job Performance. Rice Univrsity Journal.

[33] Kellerman, B. (2004). Bad Leadership: What It Is, How It Happens, Why It Matters. Boston: Harvard Business Publishing.
[34] Leet, E. (2011, march). The impact Toxic or Severe Dysfunctional Leadership has on the effectiveness of an organisation. Murdoch University.

[35] LePine, J., Hanson, M., Borman, W., \& Motowidlo, S. (2000). Contextual performance and teamwork: Implications for staffing. Research in Personnel and Human Resources Management.

[36] Lipman-Blumen, J. (2005). The Allure of Toxic Leaders. Oxford University Press.

[37] Nemeth, C. J. (1997). Managing Innovation: When Less is More. SAGE Journals.

[38] Ng, J., Ntoumanis, N., Thøgersen-Ntoumani, C., Deci, E., Ryan, R., Duda, J., et al. (2012). SelfDetermination Theory Applied to Health Contexts: A Meta-Analysis. National Library of Medicine.

[39] Ng, T., \& Feldman, D. (2012). Evaluating Six Common Stereotypes About Older Workers with Meta-Analytical Data. Journal of personnel psychology.

[40] Maxwell, S. M. (2015). An Exploration of Human Resource Personnel and Toxic Leadership. Walden Dissertations and Doctoral Studies Collection.

[41] Mehta, S., \& Maheshwari, G. (2014, October). TOXIC LEADERSHIP: TRACING THE DESTRUCTIVE TRAIL. international Journal of Management.

[42] Milliken, F. J., Morrison, E. W., \& Hewlin, P. F. (2003). An Exploratory Study of Employee Silence: Issues that Employees Don't Communicate Upward and Why. Journal of Management studies.

[43] Morris, J. A. (2019). Understanding Coping Strategies and Behaviors of Employees Affected by Toxic Leadership. Walden Dissertations and Doctoral Studies.

[44] Morrison, E. W. (2014). Employee Voice and Silence. Annual Review of Organizational Psychology and Organizational Behavior.

[45] Morrison, E., \& Milliken, F. (2000). Organizational Silence: A Barrier to Change and Development in a Pluralistic World. Academy of Management.

[46] Motowidlo, S., \& Schmit, M. (1999). Performance assessment in unique jobs. Pulakos (Eds.), The changing nature of performance, 56-86.

[47] Organ, D. W. (1988). Organizational Citizenship Behavior. Lexington Books.

[48] Pelletier, K. (2010). Leader toxicity: An empirical investigation of toxic behavior and rhetoric. Sage Publications.

[49] Perlow, L., \& Williams, S. (2003). Is silence killing your company? IEEE.

[50] Pinder, C., \& Harlos, K. (2001). Employee silence: Quiescence and acquiescence as responses to perceived injustice. Research in Personnel and Human Resources Management.

[51] Saqib, A., \& Arif, M. (2017, December). Employee Silence as a Mediator in the Relationship between Toxic Leadership Behavior and Organizational Performance. Journal of Managerial Sciences.

[52] Schilling, J., \& Kluge, A. (2009, August). Barriers to organizational learning: An integration of theory and research. British Academy of Management.

[53] Schmidt, A. A. (2008). DEVELOPMENT AND VALIDATION OF THE TOXIC LEADERSHIP 
SCALE. Faculty of the Graduate School of the University of Maryland.

[54] Schmidt, A. A. (2008). DEVELOPMENT AND VALIDATION OF THE TOXIC LEADERSHIP SCALE. Master Thesis.

[55] Starratt, A., \& Grandy, G. (2010). Young workers' experiences of abusive leadership. Leadership \& Organization Development Journal.

[56] Reilly, R., \& Aronson, Z. (2012, December). Managing Contextual Performance. ResearcgGate.

[57] Roter, A. B. (2011). The lived experiences of registered nurses exposed to toxic leadership behaviors. CAPELLA UNIVERSITY.

[58] Tangirala, S., \& Ramanujam, R. (2008). Employee Silence on Critical Work Issues: The Cross Level Effects of Procedural Justice Climate. Personnel Psychology.

[59] Tepper, B. (2007, october). Abusive Supervision, Upward Maintenance Communication, and Subordinates' Psychological Distress. The academy of management journal.

[60] Tepper, B. J. (2000). Consequences of abusive supervision. Academy of Management Journal. 